\title{
Antiretroviral treatment in HIV-I infected pediatric patients: focus on efavirenz
}

This article was published in the following Dove Press journal:

Pediatric Health, Medicine and Therapeutics

29 May 2014

Number of times this article has been viewed

\author{
Beatriz Larru' \\ Jessica Eby ${ }^{2,3}$ \\ Elizabeth D Lowentha| $\left.\right|^{2,4,5}$ \\ 'Department of Pediatrics, Division \\ of Infectious Diseases, ${ }^{2}$ Department \\ of Pediatrics, Division of General \\ Pediatrics, Children's Hospital of \\ Philadelphia, Philadelphia, ${ }^{3}$ Villanova \\ University, Villanova, ${ }^{4}$ Department \\ of Pediatrics, ${ }^{5}$ Department of \\ Epidemiology and Biostatistics, \\ University of Pennsylvania Perelman \\ School of Medicine, Philadelphia, \\ PA, USA
}

\begin{abstract}
Efavirenz is a non-nucleoside reverse transcriptase inhibitor (NNRTI), used for the treatment of human immunodeficiency virus (HIV)-1 infection. Approved by the US Food and Drug Administration in 1998, its indication was recently extended to include children as young as 3 months of age. The World Health Organization and many national guidelines consider efavirenz to be the preferred NNRTI for first-line treatment of children over the age of 3 years. Clinical outcomes of patients on three-drug antiretroviral regimens which include efavirenz are as good as or better than those for patients on all other currently approved HIV medications. Efavirenz is dosed once daily and has pediatric-friendly formulations. It is usually well tolerated, with central nervous system side effects being of greatest concern. Efavirenz increases the risk of neural tube defects in nonhuman primates and therefore its use during the first trimester of pregnancy is limited in some settings. With minimal interactions with antituberculous drugs, efavirenz is preferred for use among patients with HIV/tuberculosis coinfection. Efavirenz can be rendered inactive by a single point mutation in the reverse transcriptase enzyme. Newer NNRTI drugs such as etravirine, not yet approved for use in children under the age of 6 years, may maintain their activity following development of efavirenz resistance. This review highlights key points from the existing literature regarding the use of efavirenz in children and suggests directions for future investigation.
\end{abstract}

Keywords: efavirenz, human immunodeficiency virus, pediatrics, antiretroviral

\section{Introduction}

The number of children under the age of 15 years living with the human immunodeficiency virus (HIV) increased from 1.6 million in 2001 to 3.3 million in 2012. In 2012, there were 260,000 new infections among children less than 15 years of age. ${ }^{1}$ In the absence of treatment, approximately $50 \%$ of HIV-infected infants die before 2 years of age. ${ }^{2}$ With treatment, HIV is a chronic disease rather than a death sentence. ${ }^{3}$ Unfortunately, in 2012, only $28 \%$ of children estimated to need antiretroviral treatment (ART) in low-income and middle-income countries had access, lagging behind the $58 \%$ coverage for adults. ${ }^{1}$ Criteria for initiation of ART in HIV-infected children are summarized in Table 1.

The pathogenesis of HIV-1 and HIV-2 infection and the general virological and immunological principles underlying the use of ART are similar for all HIV-infected patients, but unique considerations exist for infected children. ${ }^{4}$ Mother-to-child transmission represents the most common cause of pediatric HIV infection, the majority of cases occurring in the peripartum period. Postpartum infection of infants occurs primarily through breastfeeding, which globally accounts for roughly one third of
Correspondence: Elizabeth D Lowenthal University of Pennsylvania Perelman School of Medicine and Children's Hospital of Philadelphia, 3535 Market Street, Room 1513, Philadelphia, PA 19104, USA

Tel +I 2674262306

Email lowenthale@email.chop.edu 
Table I When to start antiretroviral treatment in HIV-infected children according to current US, European, and WHO guidelines

\begin{tabular}{|c|c|c|c|c|}
\hline Age & Immunologic and clinical criteria & US $2012^{10}$ & PENTA 2009'1 & WHO $2013^{22}$ \\
\hline$<12$ months & $\begin{array}{l}\text { - Regardless of clinical symptoms, } \\
\text { CD4\% or viral load }\end{array}$ & $\begin{array}{l}\text { Treat }(\mathrm{Al} \text { for } \\
<12 \text { weeks of age; } \\
\text { All for }>12 \text { weeks })\end{array}$ & Treat all & $\begin{array}{l}\text { - Initiate ART in all regardless of WHO clinical } \\
\text { stage or CD4 cell count }{ }^{\mathrm{a}}\end{array}$ \\
\hline \multirow[t]{3}{*}{$\begin{array}{l}\text { I to } \\
<3 \text { years }\end{array}$} & $\begin{array}{l}\text { - AIDS or significant HIV-related } \\
\text { symptoms }^{\text {b }}\end{array}$ & Treat $\left(\mathrm{Al}^{*}\right)$ & $\begin{array}{l}\text { Treat CDC stage B } \\
\text { or } \mathrm{Cl}\end{array}$ & $\begin{array}{l}\text { - Initiate ART in all regardless of WHO clinical } \\
\text { stage and CD4 cell count }\end{array}$ \\
\hline & $\begin{array}{l}\text { - Confirmed CD4 }<25 \% \text { or CD4 } \\
\text { count }<1,000 \text { cells } / \mathrm{mm}^{3} \text {, regardless } \\
\text { of symptoms or HIV RNA level }\end{array}$ & Treat (AII) & $\begin{array}{l}\text { WHO stage } 3 \text { or } 4 \\
\text { Treat }<25 \% \text { or } \\
<\mathrm{I}, 000 \text { cells } / \mathrm{mm}^{3}\end{array}$ & $\begin{array}{l}\text { - Prioritize initiation of ART in all HIV-infected } \\
\text { children } \leq 2 \text { years of age or with severe/ } \\
\text { advanced HIV disease (WHO clinical stage } 3\end{array}$ \\
\hline & $\begin{array}{l}\text { - Asymptomatic or mild symptoms } \\
\text { and CD4 } \geq 25 \% \text { or } \geq 1,000 \text { cells } / \mathrm{mm}^{3}\end{array}$ & Consider $^{\mathrm{d}}$ (BIII) & $\begin{array}{l}\text { Consider } \\
>100,000 \text { copies } / \mathrm{mL}\end{array}$ & $\begin{array}{l}\text { or } 4 \text { ) or with CD4 count } \leq 750 \text { cells } / \mathrm{mm}^{3} \\
\text { or }<25 \%\end{array}$ \\
\hline \multirow[t]{3}{*}{$\begin{array}{l}3 \text { to } \\
<5 \text { years }\end{array}$} & $\begin{array}{l}\text { - AIDS or significant HIV-related } \\
\text { symptoms }^{\text {b }}\end{array}$ & Treat $\left(\mathrm{Al}^{*}\right)$ & $\begin{array}{l}\text { Treat CDC stage } \mathrm{B} \text { or } \\
\mathrm{Cl}\end{array}$ & \\
\hline & $\begin{array}{l}\text { - Confirmed CD4 }<25 \% \text { or CD4 } \\
\text { count }<750 \text { cells } / \mathrm{mm}^{3} \text {, regardless } \\
\text { of symptoms or HIV RNA level }\end{array}$ & Treat (AlI) & $\begin{array}{l}\text { WHO stage } 3 \text { or } 4 \\
\text { Treat }<20 \% \text { or } \\
<500 \text { cells } / \mathrm{mm}^{3}\end{array}$ & \\
\hline & $\begin{array}{l}\text { - Asymptomatic or mild symptoms } \\
\text { and CD4 } \geq 25 \% \text { or } \geq 750 \text { cells } / \mathrm{mm}^{3}\end{array}$ & Consider ${ }^{d}$ (BIII) & $\begin{array}{l}\text { Consider } \\
>100,000 \text { copies } / \mathrm{mL}\end{array}$ & \\
\hline \multirow[t]{3}{*}{$\geq 5$ years } & $\begin{array}{l}\text { - AIDS or significant HIV-related } \\
\text { symptoms }^{\text {b }}\end{array}$ & Treat $\left(\mathrm{Al}^{*}\right)$ & $\begin{array}{l}\text { Treat CDC stage } \mathrm{B} \text { or } \\
\mathrm{Cl}\end{array}$ & $\begin{array}{l}\text { - Initiate ART if CD4 cell count is } \leq 500 \text { cells/ } \\
\mathrm{mm}^{3} \text { regardless of } \mathrm{WHO} \text { clinical state }\end{array}$ \\
\hline & $\begin{array}{l}\text { - Confirmed CD4 } \leq 500 \text { cells } / \mathrm{mm}^{3} \text {, } \\
\text { regardless of symptoms or HIV } \\
\text { RNA level }\end{array}$ & $\begin{array}{l}\text { Treat }(\mathrm{Al} * \text { for } \\
\text { CD4 }<350 \text { cells } / \mathrm{mm}^{3} \\
\text { and BlI* for CD4 } \\
\left.350-500 \text { cells } / \mathrm{mm}^{3}\right)\end{array}$ & $\begin{array}{l}\text { WHO stage } 3 \text { or } 4 \\
\text { Treat }<350 \text { cells } / \mathrm{mm}^{3}\end{array}$ & $\begin{array}{l}\text { - As a priority, initiate ART in all children with } \\
\text { severe/advanced HIV disease (WHO clinical } \\
\text { stage } 3 \text { or } 4 \text { ) or CD4 count } \leq 350 \text { cells } / \mathrm{mm}^{3} \\
\text { - Initiate ART regardless of CD4 cell count }\end{array}$ \\
\hline & $\begin{array}{l}\text { - Asymptomatic or mild symptoms } \\
\text { and CD4 } \geq 500 \text { cells } / \mathrm{mm}^{3}\end{array}$ & Consider $^{d}$ (BIII) & $\begin{array}{l}\text { Consider } \\
>100,000 \text { copies } / \mathrm{mL}\end{array}$ & $\begin{array}{l}\text { - WHO clinical stage } 3 \text { or } 4 \\
\text { - Active tuberculosis }\end{array}$ \\
\hline
\end{tabular}

Notes: Rating of recommendations: A, strong, B, moderate, C, optional rating of evidence (I, one or more randomized trials in children with clinical outcomes and/or validated endpoints; $I^{*}$, one or more randomized trials in adults with clinical outcomes and/or validated laboratory endpoints with accompanying data in children from one or more well designed, nonrandomized trials or observational cohort studies with long-term clinical outcomes; II, one or more well designed, nonrandomized trials or observational cohort studies in children with long-term outcomes; I*, one or more well designed, nonrandomized trials or observational studies in adults with long-term clinical outcomes with accompanying data in children from one or more similar nonrandomized trials or cohort studies with clinical outcome data; III, expert opinion). alnitiate in all HIV-infected children younger than 18 months with a presumptive clinical diagnosis of HIV infection; ${ }^{\circ} \mathrm{CDC} C$ linical Category C and B (except for single episode of serious bacterial infection); ' $\mathrm{CDC}$ Clinical Category $\mathrm{A}$ or $\mathrm{N}$ or only a single episode of serious bacterial infection; ${ }^{\mathrm{d}}$ data supporting this recommendation are stronger if plasma HIV RNA level is $>100,000$ copies per $\mathrm{mL}$ (BII).

Abbreviations: ART, antiretroviral treatment; HIV, human immunodeficiency virus; PENTA, Pediatric European Network for Treatment of AIDS; WHO, World Health Organization; AIDS, acquired immunodeficiency syndrome; CDC, Centers for Diseases Prevention and Control.

all cases of perinatal HIV. ${ }^{5}$ HIV RNA levels remain high throughout infancy due to immaturity of the immune system. Infants have a high risk of clinical progression, regardless of their CD4+ T lymphocyte counts. ${ }^{6,7}$ Good clinical and immunological outcomes have been reported with pediatric ART. ${ }^{8,9}$ However, compared with adults, fewer children achieve virologic suppression. The lower success in pediatric treatment may be related to higher baseline viral loads, decreased innate ability to control the infection, difficulties with medication adherence, and differences in the pharmacokinetics of ART. ${ }^{10}$

As in adults, a combination of at least three antiretroviral drugs from at least two different drug classes is recommended for the initial treatment of HIV-infected infants and children. ${ }^{11}$ These ART combinations provide the best opportunity to preserve immune function and halt disease progression. ${ }^{12}$ In choosing pediatric ART regimens, practitioners consider the safety profile, drug potency, availability of pediatric formulations, and compatibility with other drugs. ${ }^{10}$ Consistent high-level adherence to ART is critical. Barriers to adherence include frequent dosing, food and fasting requirements for some drugs, high pill burdens/liquid volumes, palatability problems, and drug toxicities. ${ }^{13}$ Poor adherence can result not only in treatment failure, but also in resistance to available antiretroviral agents (ARVs). ${ }^{14}$

Treatment of HIV infection in children is complicated by the fact that most ARVs are approved for pediatric use on the basis of efficacy data extrapolated from adult studies, with only limited pediatric pharmacokinetic data. Adult dosing does not directly translate to pediatric dosing, particularly in young infants, and the likelihood of toxicity and viral resistance may be increased by physiologic changes that introduce pharmacokinetic variability during maturation. ${ }^{15}$ More than 25 ARVs are licensed worldwide for the treatment of HIV-infected adults, but many are unlicensed and/or do not have appropriate formulations for children up to 2 years 
of age (Table 2). Treatment options for children are therefore limited, especially in resource-poor settings. ${ }^{16}$

Although ART remains unavailable to most HIV-infected children worldwide, tremendous advances in treatment access have been made in the last decade, bringing a new era of hope in communities previously devastated by HIV. ${ }^{17}$ Firstline treatment in children typically involves two drugs from the nucleoside reverse transcriptase inhibitor (NRTI) family and one drug from either the non-nucleoside reverse transcriptase inhibitor (NNRTI) or protease inhibitor families. In both resource-limited and high-resource settings, the NNRTI efavirenz is commonly included in first-line regimens for children over the age of 3 years. This review focuses on the use of efavirenz in infants, children, and adolescents, and highlights future avenues for research related to use of this agent.

\section{NNRTI in the treatment of HIV-infected children}

ARVs are classified into five major classes: NRTIs, NNRTIs, protease inhibitors, entry inhibitors (including fusion inhibitors and CCR5 antagonists), and integrase

Table 2 List of currently available antiretroviral treatments with US Food and Drug Administration approval by age group

\begin{tabular}{|c|c|c|}
\hline Drug class & Antiretroviral & $\begin{array}{l}\text { FDA-approved } \\
\text { age }\end{array}$ \\
\hline Nucleoside/nucleotide* & Abacavir & $\geq 3$ months \\
\hline reverse transcriptase & Didanosine & $\geq 2$ weeks \\
\hline \multirow[t]{5}{*}{ inhibitors } & Emtricitabine & Birth \\
\hline & Lamivudine & Birth \\
\hline & Stavudine & Birth \\
\hline & Tenofovir* & $\geq 2$ years \\
\hline & Zidovudine & Birth \\
\hline Non-nucleoside reverse & Efavirenz & $\geq 3$ months \\
\hline \multirow[t]{3}{*}{ transcriptase inhibitors } & Etravirine & $\geq 6$ years \\
\hline & Nevirapine & Birth \\
\hline & Rilpivirine & $\geq 18$ years \\
\hline \multirow[t]{9}{*}{ Protease inhibitors } & Atazanavir & $\geq 6$ years \\
\hline & Darunavir & $\geq 3$ years \\
\hline & Fosamprenavir & $\geq 6$ months \\
\hline & Indinavir & $\geq 18$ years \\
\hline & Lopinavir & $\geq 2$ weeks \\
\hline & Nelfinavir & $\geq 2$ years \\
\hline & Ritonavir & $\geq I$ month \\
\hline & Saquinavir & $\geq 2$ years \\
\hline & Tipranavir & $\geq 2$ years \\
\hline CCR5 antagonist & Maraviroc & $\geq 16$ years \\
\hline \multirow[t]{2}{*}{ Integrase inhibitors } & Raltegravir & $\geq 18$ years \\
\hline & Elvitegravir & $\geq 18$ years \\
\hline Fusion inhibitor & Enfuvirtide & $\geq 6$ years \\
\hline
\end{tabular}

Note: *Tenofovir is a nucleotide reverse transcriptase inhibitor whereas the rest of the drugs in this class are nucleoside analogs. Abbreviation: FDA, US Food and Drug Administration. inhibitors (Table 2). ${ }^{10}$ NNRTIs bind directly and noncompetitively to reverse transcriptase, causing a conformational change and disrupting the enzyme's catalytic site. ${ }^{18}$ Because of the Y188L polymorphism present naturally in HIV-2, NNRTIs are not effective for the treatment of HIV-2. ${ }^{19}$

Currently there are four NNRTIs licensed for the treatment of HIV in adults, ie, nevirapine, efavirenz, etravirine, and rilpivirine. The first-generation NNRTIs, nevirapine and efavirenz, fulfill key roles in ART for HIV-infected children. They are extensively utilized both for lowering the incidence of mother-to-child transmission and for treatment throughout childhood and adolescence. ${ }^{20}$ US and European guidelines recommend the use of ART comprising two NRTIs with either an NNRTI or a protease inhibitor, and the 2013 World Health Organization (WHO) guidelines recommend two NRTIs plus an NNRTI as first-line ART for HIV-1 in adults and children over the age of 3 years. Efavirenz is considered the preferred agent and nevirapine is an acceptable alternative (Table 3$) \cdot{ }^{10,21,22}$

Table 3 Comparison of guidelines for preferred first-line antiretroviral treatment in treatment-naïve pediatric patients

\begin{tabular}{|c|c|c|}
\hline US $2012^{10}$ & PENTA 2009²1 & WHO $2013^{22}$ \\
\hline \multicolumn{3}{|c|}{ Infants and children $<3$ years } \\
\hline $\begin{array}{l}\mathrm{LPV} / \mathrm{r}+\mathrm{ZDV}+ \\
(3 \mathrm{TC} \text { or FTC) } \\
\geq 3 \text { months: } \mathrm{LPV} / \mathrm{r}+ \\
\mathrm{ABC}+(3 \mathrm{TC} \text { or } \mathrm{FTC})\end{array}$ & $\begin{array}{l}\mathrm{NFV}+(\mathrm{ABC} \text { or } \\
\mathrm{ZDV})+3 \mathrm{TC} \\
\text { or } \\
\mathrm{LPV} / \mathrm{r}+(\mathrm{ABC} \text { or } \\
\mathrm{ZDV})+3 \mathrm{TC}\end{array}$ & $\begin{array}{l}\mathrm{LPV} / \mathrm{r}+(\mathrm{ABC} \text { or } \\
\mathrm{ZDV})+3 \mathrm{TC}\end{array}$ \\
\hline \multicolumn{3}{|l|}{ Children $\geq 3$ years } \\
\hline $\begin{array}{l}\mathrm{EFV}+(\mathrm{ABC} * \text { or } \mathrm{ZDV})+ \\
(3 \mathrm{TC} \text { or FTC) }\end{array}$ & $\begin{array}{l}E F V+(A B C \text { or } \\
Z D V)+3 T C\end{array}$ & $\begin{array}{l}\mathrm{EFV}+\mathrm{ABC}+ \\
3 \mathrm{TC}\end{array}$ \\
\hline or & or & \\
\hline $\begin{array}{l}\mathrm{LPV} / \mathrm{r}+(\mathrm{ABC} \text { or } \mathrm{ZDV})+ \\
(3 \mathrm{TC} \text { or FTC) }\end{array}$ & $\begin{array}{l}\mathrm{LPV} / \mathrm{r}+(\mathrm{ABC} \text { or } \\
\mathrm{ZDV})+3 T C\end{array}$ & \\
\hline or & & \\
\hline \multicolumn{3}{|l|}{$\begin{array}{l}A T V / r+(A B C \text { or } Z D V)+ \\
(3 T C \text { or } F T C) \text { if } \geq 6 \text { years }\end{array}$} \\
\hline Adolescents & & \\
\hline $\begin{array}{l}\text { EFV + TDF/FTC } \\
\text { or }\end{array}$ & $\begin{array}{l}E F V+(A B C \text { or } \\
Z D V)+3 T C\end{array}$ & $\begin{array}{l}\mathrm{EFV}+\mathrm{TDF}+ \\
\text { (3TC or FTC) }\end{array}$ \\
\hline $\begin{array}{l}\mathrm{ATV} / \mathrm{r}+\mathrm{TDF} / \mathrm{FTC} \\
\text { or }\end{array}$ & & \\
\hline $\begin{array}{l}\text { DRV/r + TDF/FTC } \\
\text { or } \\
\text { RAL + TDF/FTC }\end{array}$ & & \\
\hline
\end{tabular}

Notes: *HLA-B*570I genetic tests should be performed before initiating abacavirbased therapy in this setting, and abacavir should not be given to a child who tests positive for HLA-B*570I.

Abbreviations: $3 T C$, lamivudine; $A B C$, abacavir; ARV, antiretroviral; $A T V$, atazanavir; EFV, efavirenz; FTC, emtricitabine; LPV/r, lopinavir/ritonavir; NNRTI, nonnucleoside reverse transcriptase inhibitor; NRTI, nucleoside reverse transcriptase inhibitor; NVP, nevirapine; Pl, protease inhibitor; RAL, raltegravir; RTV, ritonavir; TDF, tenofovir; RPV, rilpivirine; ZDV, zidovudine. 
Efavirenz-containing regimens have shown equivalent or superior virologic and immunologic responses compared with nevirapine. ${ }^{23}$ Efavirenz is commonly used to compare the efficacy of newer ARVs. It is dosed once daily and can be coadministered with antituberculosis medications. It is available in child-friendly formulations and in a one pill once a day fixed-dose combination for adolescents and adults. $^{24,25}$ For all these reasons, it is used widely in HIVinfected children.

The second generation of NNRTIs, etravirine and rilpivirine, were developed to offer a higher genetic barrier to resistance and to improve tolerability. ${ }^{26,27}$ These drugs currently lack indications for young children, but may be useful second-line agents for older children who have developed resistance to first-line NNRTIs. ${ }^{28}$

\section{Pediatric use of efavirenz}

Efavirenz was approved by the US Food and Drug Administration (FDA) in 1998 and quickly became an important component of ART. ${ }^{29}$ Efavirenz noncompetitively inhibits wild-type HIV-1 reverse transcriptase without inhibiting human cellular DNA polymerases. It has antiretroviral activity against most HIV-1 isolates, but has reduced activity against group $\mathrm{O}$ viruses. ${ }^{24}$

Data on pediatric use of efavirenz that led to its approval derived from the Pediatric AIDS Clinical Trials Group (PACTG) 382 study, in which 57 HIV-infected NRTI-pretreated children received efavirenz in combination with nelfinavir and one or two NRTIs. The drugs were well tolerated and led to sustained virologic suppression in most children over the age of 3 years. Almost 15 years after the publication of the PACTG 382 study results, additional studies have shown efavirenz to be an effective option for treatment of pediatric HIV in both treatment-naïve and heavily pretreated children. ${ }^{30}$ In May 2013, the FDA expanded the indication for efavirenz to children as young as 3 months of age. A summary of trials assessing the efficacy and safety of efavirenz in naïve and pretreated children is shown in Table 4. Most of these studies included relatively small numbers of patients and less than 24 months of follow-up time. A large study in Botswana with a median follow-up of more than 5 years had limited toxicity data available. Multisite studies of long-term outcomes and toxicities are still needed.

\section{Nevirapine versus efavirenz ARV regimens in children}

Until 2010, the WHO recommended either nevirapine or efavirenz in first-line ART regimens as equally acceptable alternatives. Citing a meta-analysis of seven randomized controlled trials $(n=1,688)$ comparing nevirapine and efavirenz, the 2010 WHO ART guidelines for adults and adolescents deemed that the two NNRTIs had comparable efficacy, although toxicity profiles favored efavirenz for many patients. ${ }^{31}$ None of the seven trials examined in the meta-analysis, however, included children. In light of more recent data showing better outcomes in adults on efavirenz, the WHO 2013 guidelines name efavirenz as the preferred NNRTI. Evidence from pediatric studies is similar. A retrospective cohort study of children aged $3-16$ years on efavirenz-based $(n=421)$ or nevirapinebased $(n=383)$ regimens in Botswana found a $13.5 \%(95 \%$ confidence interval [CI] 10.4-17.2) virologic failure rate among those on efavirenz-based treatment compared with a 26.4\% (95\% CI 22.0-31.1) virologic failure rate among those on nevirapine-based treatment. ${ }^{32}$ The Cox proportional hazard ratio for failure was 2.0 (95\% CI 1.4-2.7; $\log$ rank $P<0.001$, favoring efavirenz). In a prospective observational cohort study of 250 children aged $0-18$ years in Uganda, patients on nevirapine-based therapy were similarly more likely to experience virologic failure than those receiving efavirenz-based treatment (odds ratio 2.5; 95\% CI 1.2-4.9). ${ }^{33}$

Efavirenz is dosed once daily and comes in variably sized capsules and fixed-combination tablets with emtricitabine and tenofovir. A liquid formulation is also available, although its decreased bioavailability and increased pharmacokinetic variability make it a less used option. ${ }^{34}$ Nevirapine is available as a tablet or oral suspension and is usually taken twice daily. An extended-release formulation of nevirapine has recently been shown to have acceptable trough levels in children. ${ }^{35}$ Nevirapine requires a lead-in period (typically 2 weeks) during which half-doses are administered. Nevirapine has also been associated with a higher risk of NNRTI resistance mutations than efavirenz. ${ }^{36,37} \mathrm{~A}$ higher risk of resistance may be particularly problematic among adolescent patients, who have the poorest adherence rates when compared with both adults and younger children. ${ }^{1,38}$

The cost (single dose/fixed-dose combination) of efavirenz $(\$ 52 / \$ 180)$ remains higher than nevirapine $(\$ 31 / \$ 131)$, but the WHO reports that the price gap is narrowing., ${ }^{2,31,39}$ The dropping of the price of efavirenz coupled with the accumulating evidence of its superior clinical effectiveness, safety, and convenience suggest that efavirenz will increasingly be the preferred NNRTI for first-line ART in low-resource settings. 


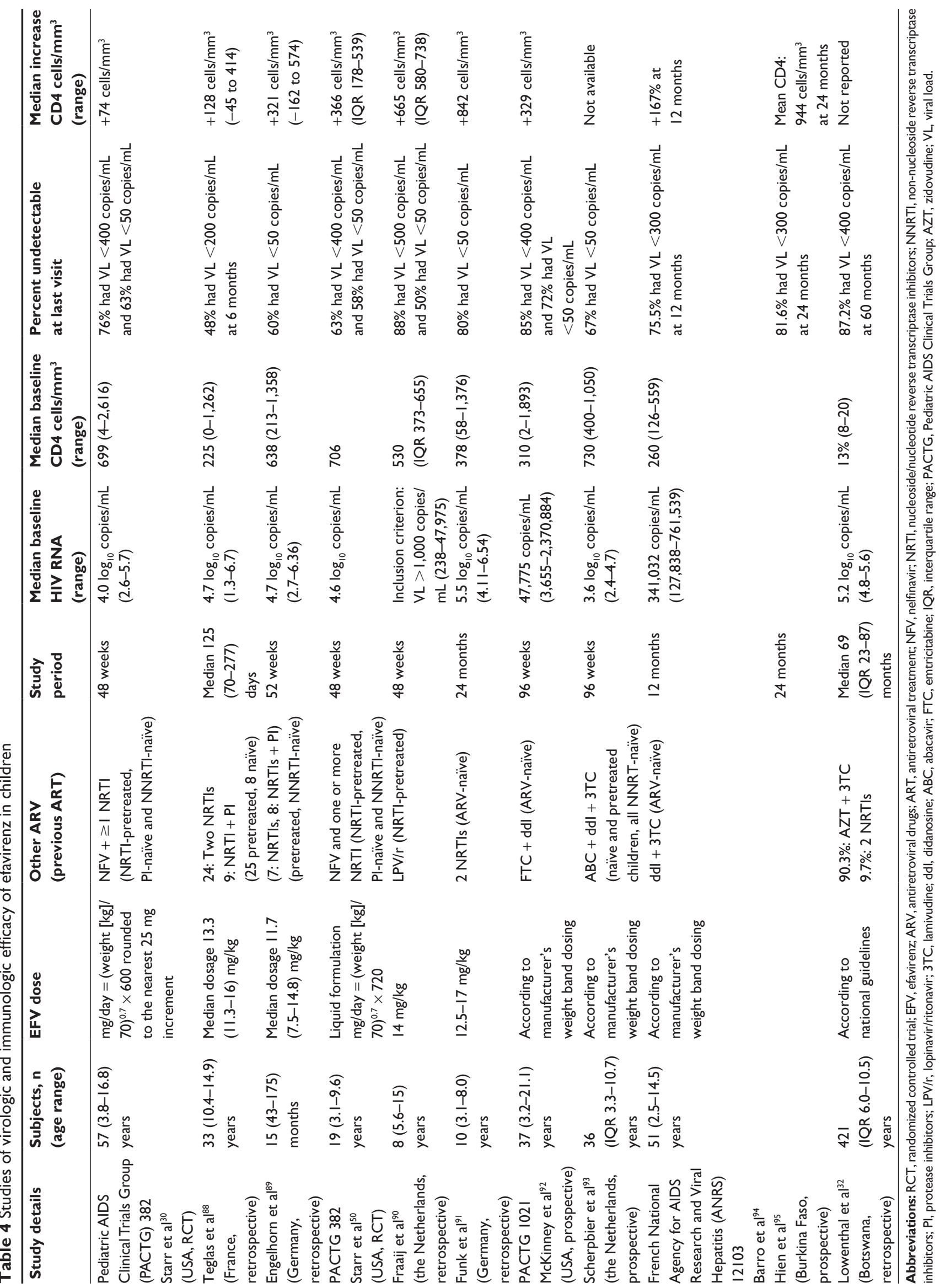




\section{NNRTI-based versus protease inhibitor-based ARV regimens in children}

Preferred regimens for initial ART in children include both NNRTI-boosted and ritonavir-boosted protease inhibitorbased regimens (Table 3). Both types of regimen have good virological and immunological efficacy. NNRTIs generally are lower in cost, have lower pill burdens, and have fewer metabolic complications, such as dyslipidemia, fat redistribution, and insulin resistance, compared with protease inhibitor-based regimens. The first-generation NNRTIs are available as generic formulations in many low-income and middle-income countries as well as fixed-dose combinations that do not require a cold chain. Given that most HIV-infected children live in sub-Saharan Africa and will require lifelong therapy, these are important considerations for pediatric HIV treatment.

Both efavirenz and nevirapine can be rendered ineffective by a single point mutation, and cross-resistance between the two drugs is common. Boosted protease inhibitors have a higher barrier to resistance and are more forgiving of adherence lapses. However, with lower pill burden and once-daily dosing, adherence may be less of a challenge for patients on efavirenz. ${ }^{3,40}$

The PENPACT-1 (PENTA-9/PACTG 390) study provided a head-to-head comparison of pediatric outcomes among 263 infants and children (age 30 days to 18 years) given NNRTIbased and protease inhibitor-based regimens. The 131 children in the NNRTI groups received either efavirenz or nevirapine (61\% and $38 \%$, respectively) and the 132 children in the protease inhibitor-based groups received lopinavir/ritonavir or nelfinavir ( $49 \%$ and $48 \%$, respectively). Efavirenz was only given to children $\geq 3$ years. After 4 years, $73 \%$ of the children on protease inhibitor-based therapy and $70 \%$ of the children on NNRTI-based therapy remained on their initial ART regimen with no significant difference in the mean reduction in viral load between the groups. ${ }^{1,41}$ This contrasts with the results of the International Maternal Pediatric Adolescent AIDS Clinical Trials Group (IMPAACT) 1060 trial (see Development of efavirenz resistance in children section) that found a significantly higher rate of virological failure, treatment discontinuation, or death at 24 weeks in children aged $<3$ years on nevirapineregimens compared with lopinavir/ritonavir., ${ }^{4,42,43}$ Switching from protease inhibitor-based regimens to NNRTI in order to simplify ART after virologic suppression can result in improvements in total cholesterol, low-density lipoprotein cholesterol, triglycerides, and the cholesterol/high-density lipoprotein cholesterol ratio, while maintaining virologic suppression and immunologic benefits. ${ }^{5,44}$

\section{Dosing and pharmacokinetics of efavirenz in children}

Efavirenz is available in $50 \mathrm{mg}$ and $200 \mathrm{mg}$ capsules and in $600 \mathrm{mg}$ film-coated tablets. A tablet combining efavirenztenofovir-emtricitabine $\left(600 \mathrm{mg} / 300 \mathrm{mg} / 200 \mathrm{mg}\right.$, Atripla ${ }^{\circledR}$, Bristol-Myers Squibb and Gilead Sciences, LLC, Foster City, CA, USA) is also approved for once-daily, single tablet administration in HIV-infected adolescents and adults. ${ }^{6,7,25}$ Efavirenz should be administered on an empty stomach, preferably at bedtime, to improve its tolerability. The contents of the efavirenz capsules (sprinkles) can be given with 1-2 teaspoons of food for those who cannot swallow capsules. This dosing method has been shown to be bioequivalent to a single dose of efavirenz $600 \mathrm{mg}$ given as an intact capsule under fasting conditions in healthy adults. ${ }^{8,9,45}$ Although less data are available to recommend this practice in children, administration of sprinkles to children with small amounts of food is common.

The pharmacokinetics of efavirenz are best described by a one-compartment model with first-order absorption and elimination. Efavirenz is a mixed inducer/inhibitor of cytochrome P450 (CYP)3A4 enzymes. The main pharmacokinetic properties of efavirenz are summarized in Figure 1. Its prolonged half-life (40-55 hours) enables once-daily dosing. The prescribing recommendations for efavirenz in children utilize weight-band dosing, with allometric doses targeting at least $300 \mathrm{mg} / \mathrm{m}^{2}$ in each band. ${ }^{10,18,24,29}$ Although dosing for children as young as 3 months and as small as $3.5 \mathrm{~kg}$ was recently approved by the FDA, there are concerns about increased pharmacokinetic variability in the youngest children. ${ }^{11,46,47}$ Plasma concentrations of efavirenz between $1.0 \mathrm{mg} / \mathrm{L}$ and $4.0 \mathrm{mg} / \mathrm{L}(3-13 \mu \mathrm{mol} / \mathrm{L}) 8-20$ hours after ingestion is recommended for achieving long-term HIV RNA suppression and for limiting side effects. Studies evaluating the pharmacokinetics of efavirenz in children are sparse, but consistently indicate a high prevalence of virological failure with a plasma efavirenz concentration $<1.0 \mathrm{mg} / \mathrm{L}$ (Table 5). In a West African pediatric study (ANRS 12103), reduction in viral load by 12 weeks was greater in children with minimum plasma efavirenz concentrations greater than $1.1 \mu \mathrm{g} / \mathrm{mL}$ or area under the curve (AUC) greater than $51 \mu \mathrm{g} *$ hour $/ \mathrm{mL}$. In PACTG 382, $40 \%$ of children on efavirenz had their daily doses of efavirenz increased based on assessments of the 24-hour AUCs 2 weeks after initiation. ${ }^{12,30}$ Subsequent pediatric studies, using slightly higher doses than PACTG 382 , found an even greater proportion of children with a minimum plasma concentration $<1 \mathrm{mg} / \mathrm{L}$, particularly among younger children with lower weights. ${ }^{10,48}$ Mutwa et al found 
- Oral bioavailability of EFV is $40 \%-45 \%$ without food

- Time to peak EFV plasma concentration $\left(\mathrm{C}_{\max }\right)$ is $\sim 2-5$ hours

- Steady-state plasma concentrations are reached in 6-10 days

- Food intake with EFV ingestion increases the $C_{\max }$ and $A U C$ by $40 \%-80 \%$ and $15 \%-30 \%$ respectively compared with fasting. It is therefore recommended to avoid administration of EFV with a high-fat meal because of potential for increased absorption

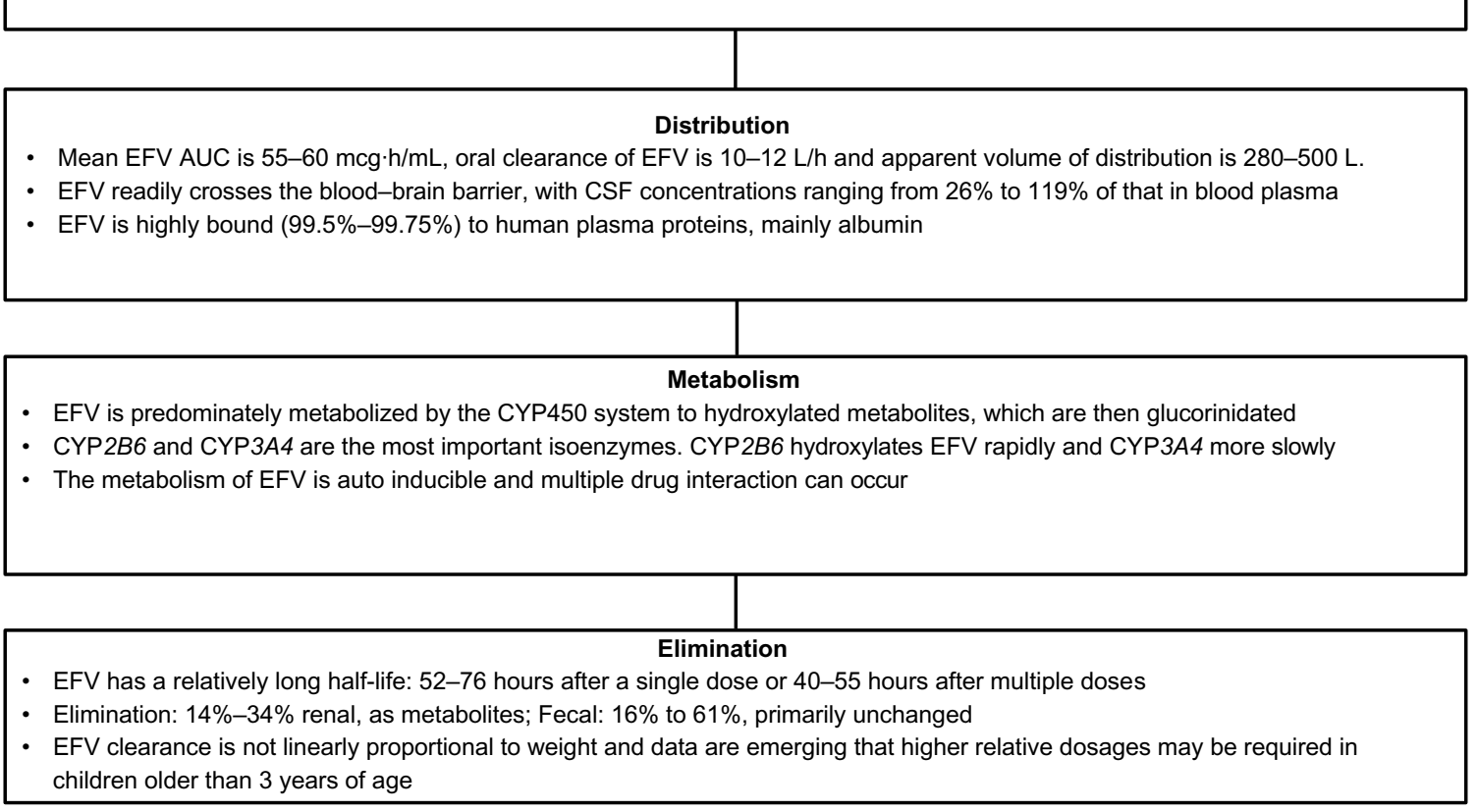

Figure I Pharmacology and pharmacokinetics of efavirenz.

Abbreviations: $\mathrm{EFV}$, efavirenz; $\mathrm{C}_{\text {max }}$, peak concentration; $\mathrm{AUC}$, area under curve; CSF, cerebrospinal fluid.

large interpatient variability in plasma efavirenz concentrations among 97 Rwandan children, with a third of children having subtherapeutic concentrations. ${ }^{49}$ The use of the liquid formulation of efavirenz in PACTG 382 led to even lower AUCs, with $61 \%$ of children requiring a dose increase after 2 weeks of therapy. ${ }^{14,50}$

Efavirenz is metabolized by polymorphically expressed enzymes, allowing for high interpatient pharmacokinetic variability. CYP2B6-G516T gene polymorphisms have been shown to affect expression of CPY $2 B 6$ in the liver. ${ }^{15,51}$ The CYP2B6 T/T or G/T genotype at position 516 is more common in African-Americans and is associated with greater plasma efavirenz exposure compared with the $\mathrm{G} / \mathrm{G}$ genotype. Other polymorphisms in CYP2B6 such as 785AA are strongly associated with lower efavirenz levels compared with $785 \mathrm{GG}$ and $785 \mathrm{AG}$. Efavirenz has higher clearance among whites, non-Hispanics and males compared with African-Americans, Hispanics, and females. These findings are consistent in both adults and children. ${ }^{16,49}$ Saitoh et al found that CYP2B6-G516T gene polymorphisms significantly affect the median oral clearance rate of efavirenz in 71 HIV-infected children. Variability in plasma efavirenz levels is also associated with nongenetic factors, such as body weight, concomitant medications, and nonadherence. ${ }^{17,52}$ Higher plasma efavirenz concentrations are associated with increased toxicity. ${ }^{10,53,54}$

The use of efavirenz is recommended for those with tuberculosis coinfection since drug-drug interactions with rifampin are a considerable problem with both nevirapine and protease inhibitors. The impact that CYP $2 B 6$ polymorphisms have on children receiving efavirenz concomitant with antituberculosis treatment has recently been studied by McIlleron et al. Their findings, consistent with several adult studies, support maintaining usual efavirenz doses in children being treated for tuberculosis with rifampicin-containing regimens. ${ }^{18,55,56}$

\section{Safety and effectiveness of efavirenz in children}

A summary of the adverse events reported in efavirenzbased ART regimens in children is shown in Table 6. The most commonly discussed toxicities of efavirenz are neuropsychiatric adverse reactions. ${ }^{19,57}$ Mild to moderate events such as dizziness, sleep disturbances, vivid dreams, nightmares, impaired concentration, and hallucinations have been reported in about $50 \%$ of adult patients and last for a 
Table 5 Pharmacokinetic studies of efavirenz in children reporting a high proportion of children with subtherapeutic plasma efavirenz concentrations

\begin{tabular}{|c|c|c|c|c|}
\hline Study details & $\begin{array}{l}\text { Number of } \\
\text { subjects } \\
\text { (age range) }\end{array}$ & $\begin{array}{l}\text { Other ARV } \\
\text { (Previous ART) }\end{array}$ & EFV dose & Results \\
\hline $\begin{array}{l}\text { Ren et al }{ }^{96} \\
\text { (South Africa, } \\
\text { case series) }\end{array}$ & $15(2.3-11.3)$ years & $\begin{array}{l}\text { I3: EFV + d4T + 3TC } \\
\text { I: EFV + ZDV + 3TC } \\
\text { I: EFV + ZDV + ddI }\end{array}$ & $\begin{array}{l}\text { Manufacturer's weight } \\
\text { band dosing }\end{array}$ & $\begin{array}{l}\mathrm{C}_{\min }<\mathrm{I} \mathrm{mg/L} \text { in } 6(40 \%) ; 5 \text { children had } \\
\text { detectable VL, } 3 \text { of whom had low EFV } \\
\text { concentrations; marked variability of EFV levels }\end{array}$ \\
\hline $\begin{array}{l}\text { French National } \\
\text { Agency for AIDS } \\
\text { Research and Viral } \\
\text { Hepatitis (ANRS) } \\
\text { I2I03 Hirt et al }\left.\right|^{47} \\
\text { (Burkina Faso, } \\
\text { prospective) }\end{array}$ & $\begin{array}{l}48 \text { ( } 30 \text { months } \\
\text { to I } 5 \text { years) }\end{array}$ & $\begin{array}{l}\text { EFV-ddl-3TC } \\
\text { (ARV-naïve) }\end{array}$ & $\begin{array}{l}\text { Manufacturer's weight } \\
\text { band dosing }\end{array}$ & $\begin{array}{l}19 \%(44 \% \text { of children weighting }<15 \mathrm{~kg}) \\
\text { had } C_{\text {min }}<1 \mathrm{mg} / \mathrm{L} \\
\text { Significantly higher percentage of children with } \\
C_{\min }>1.1 \mathrm{mg} / \mathrm{L} \text { or } A U C \mathrm{~s}>5 \mathrm{I} \mathrm{mg} / \mathrm{L} \text { hour than } \\
\text { of children with lower values had viral load } \\
\text { decreases greater than } 2 \log _{10} \text { copies } / \mathrm{mL} \text { after } \\
3 \text { months of treatment }\end{array}$ \\
\hline $\begin{array}{l}\text { Viljoen et a }{ }^{97} \\
\text { (South African, } \\
\text { prospective) }\end{array}$ & $60(3-14)$ years & $\begin{array}{l}\mathrm{EFV}+\mathrm{d} 4 \mathrm{~T}+3 \mathrm{TC} \\
(\mathrm{ARV} \text {-naïve) }\end{array}$ & $\begin{array}{l}200,250,300,350,400 \text {, and } \\
600 \mathrm{mg} \text { daily for children } \\
\text { weighing } 10-14.9,15-19.9 \\
20-24.9,25-32.9,33-40 \\
\text { and }>40 \mathrm{~kg} \text {, respectively }\end{array}$ & $\begin{array}{l}\text { From } \mathrm{I} 64 \text { samples taken at } \mathrm{I}, 3 \text {, and } 6 \text { months } \\
\text { after initiation: } \\
\mathrm{C}_{\min }<\mathrm{Img} / \mathrm{L} \text { in } \mathrm{I} \% \\
\mathrm{C}_{\min }<\mathrm{I}-4 \mathrm{mg} / \mathrm{L} \text { in } 58 \% \\
\mathrm{C}_{\min }>4 \mathrm{mg} / \mathrm{L} \text { in } 25 \%\end{array}$ \\
\hline $\begin{array}{l}\text { Antiretroviral } \\
\text { Research for } \\
\text { Watoto (ARROW) }\end{array}$ & $4 I(3-12)$ years & $E F V+A B C+3 T C$ & $\begin{array}{l}2006 \mathrm{WHO} / \text { manufacturer's } \\
\text { recommended dosage }\end{array}$ & $\begin{array}{l}\text { PKI at steady state; PK2 } 4 \text { weeks after } \\
\mathrm{C}<\mathrm{I} \mathrm{mg/L} \mathrm{in} 7 \text { (I7\%) at } 8 \text { and/or } 12 \text { hours } \\
\text { after dosing }\end{array}$ \\
\hline $\begin{array}{l}\text { PK Fillekes et } \mathrm{al}^{48} \\
\text { (Uganda, RCT) }\end{array}$ & & & & $\begin{array}{l}\mathrm{C}_{\min }<\mathrm{I} \mathrm{mg/L} \text { in } \mathrm{I} 5 \text { of } 39(3 \%) \text { with } \mathrm{C}_{24 \mathrm{~h}} \text { median } \\
\mathrm{I} . \mathrm{I} \text { (interquartile range } 0.7-2.9 \text {; range } 0.3-18.4) \\
\mathrm{C}_{8 \mathrm{~h}} \text { and/or } \mathrm{C}_{12 \mathrm{~h}}>4.0 \mathrm{mg} / \mathrm{L} \text { in } \mathrm{I} 2 \text { of } 4 \mathrm{I}(29 \%)\end{array}$ \\
\hline $\begin{array}{l}\text { Cressey et } \mathrm{a}^{98} \\
\text { (Thailand, } \\
\text { prospective) }\end{array}$ & $39(3-17)$ years & $\begin{array}{l}\mathrm{EFV}+\mathrm{TDF}+3 \mathrm{TC} \\
(\mathrm{ARV} \text {-naïve) }\end{array}$ & $\begin{array}{l}250,300,350,400 \text {, and } \\
600 \mathrm{mg} \text { daily for children } \\
\text { weighing } 15-20,20-25 \text {, } \\
25-32.5,32.5-40 \text {, or } \\
>40 \mathrm{~kg} \text {, respectively }\end{array}$ & $\begin{array}{l}\mathrm{C}_{\min }<\mathrm{Img} / \mathrm{L} \text { in } 6(15 \%) \text {, including } 2 \text { of } 4 \text { in the } \\
\text { lowest weight band }\end{array}$ \\
\hline
\end{tabular}

Abbreviations: EFV, efavirenz; d4T, stavudine; 3TC, lamivudine; $C_{\text {min }}$ minimum concentrations; ARV, antiretroviral; ddl, didanosine; ZDV, zidovudine; PK, pharmacokinetic; TDF, tenofovir; ABC, abacavir; WHO, World Health Organization; RCT, randomized controlled trial; ART, antiretroviral treatment; VL, viral load.

median of 21-28 days, with therapy being discontinued in approximately $2 \%$ of patients. ${ }^{20,58,59}$ Taking efavirenz with meals may increase AUC and adverse events. Taking it on an empty stomach at bedtime improves tolerability. ${ }^{10,20-22,60}$ Some patients continue to experience neuropsychiatric adverse events and impairment of quality of life well after one month..$^{23,61,62}$

Assessment of central nervous system toxicity is difficult in young children, who are typically unable to report such problems as inability to concentrate, disturbed sleep, and feeling less steady. Subtle efavirenz-induced changes in behavior and slowing of developmental progress may be impossible to distinguish, particularly in children who are beginning HIV treatment while recovering from severe HIV-related illnesses. These children may show dramatic health improvements due to their immunologic recovery, while side effects that negatively impact their development go unnoticed. In a cohort of 378 HIV-infected children in Uganda on NNRTI-based regimens, 28\% developed ART-related adverse events during the 5-year study period. Neurologic events were reported in $16 \%$ of patients $(65 \%$ of them in the efavirenz-based regimens). In this study, central nervous system events were not assessed in children younger than 5 years. . $4,25,63^{-}$

In resource-constrained settings, there is a particular paucity of information on ART-related adverse events in children. Implementation of the WHO 2010 efavirenz dosing guidelines may result in increased virologic suppression rates, but higher numbers of children experiencing efavirenzrelated adverse events. The increased potential for sleep disturbances and impaired concentration during periods of rapid brain development should cause prescribers to carefully monitor mental and physical development among young patients on efavirenz. A high index of suspicion is necessary to detect most neuropsychiatric side effects in children. With side effects considered to be mild, the benefits of continuing the drug may outweigh the risks, particularly in areas where drug options are limited.

During the first 2 weeks of treatment, about $5 \%-20 \%$ of adults will develop a skin rash, approximately half the incidence reported with nevirapine. Rashes are more common 


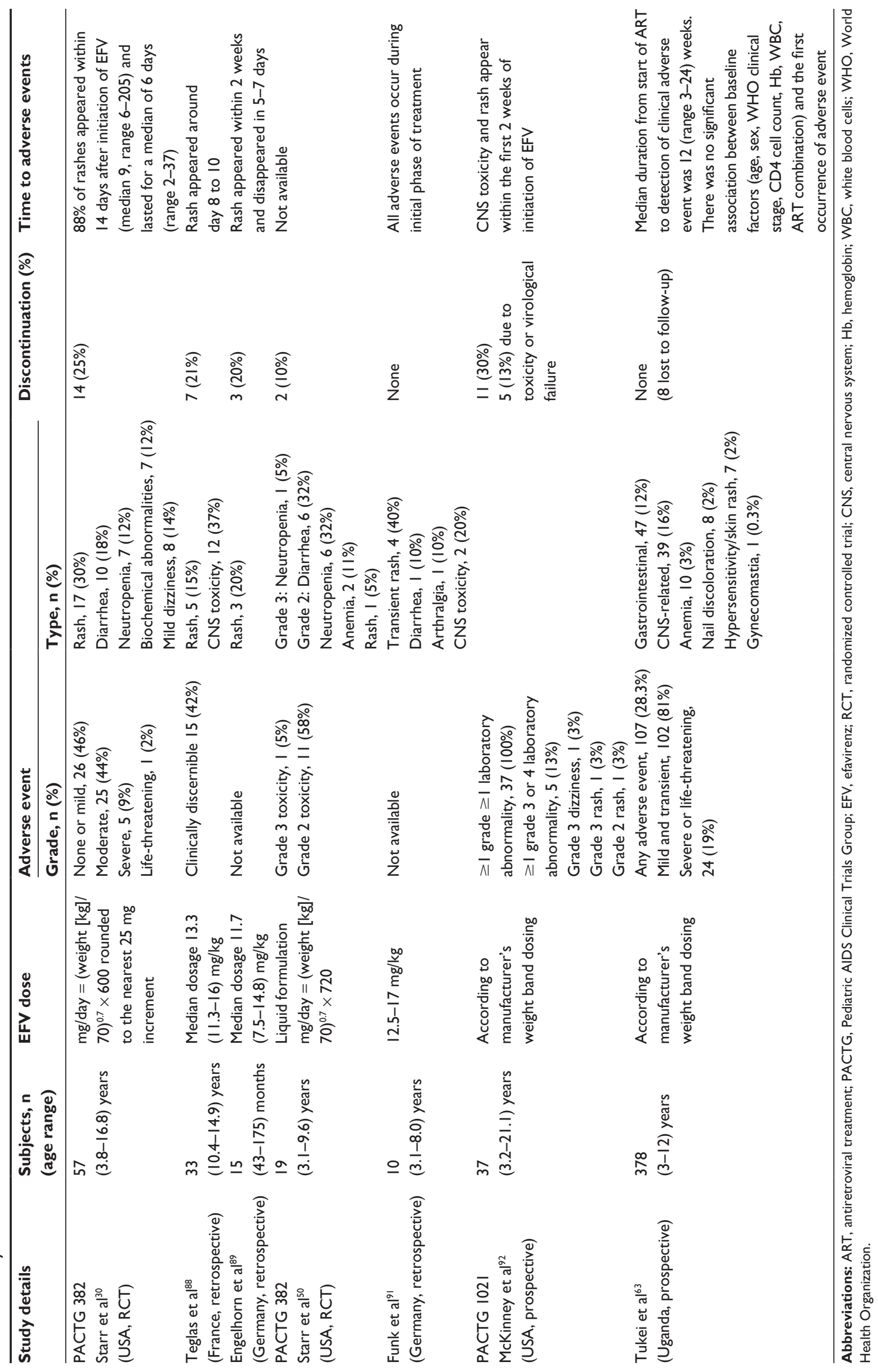


in pediatric patients initiating efavirenz, occurring in up to a third of patients. Efavirenz-related rashes in children occur later than those in adults, with a median time of onset of 28 days. The rashes seen in both children and adults are presumed to be cell-mediated hypersensitivity reactions. Most efavirenz-related rashes resolve within one month without need for drug discontinuation. Severe dermatologic toxicity, such as Stevens-Johnson syndrome, occurs in about $0.1 \%$ of cases. Antihistamines and corticosteroids can improve symptoms and hasten resolution of these rashes..$^{20,26,27}$

Hepatic monitoring is recommended for patient initiating efavirenz with underlying liver disease and those on other drugs with potential for hepatic side effects. Hepatotoxicity is more commonly seen with nevirapine $(1.4 \%-17 \%)$ than efavirenz $(1.1 \%-8 \%){ }^{28,64}$

A recent meta-analysis of the adverse events associated with nevirapine and efavirenz-based first-line regimens showed that adults on nevirapine were more than twice as likely to discontinue treatment due to adverse events compared with those on efavirenz (odds ratio 2.2, 95\% CI 1.9-2.6). Severe dermatologic and hepatic toxicities were more likely among patients on nevirapine. However, patients receiving efavirenz were more likely to experience severe central nervous system events (odds ratio 3.4, 95\% CI 2.1-5.4). This meta-analysis included four prospective trials conducted in children with similar associations. ${ }^{29,65}$

Switching between NNRTI due to toxicities is sometimes recommended. Switches from efavirenz to nevirapine can be helpful in the event of severe persistent neuropsychiatric adverse events. Substituting efavirenz for nevirapine can decrease hepatotoxicity. However, switching between drugs when severe life-threatening rashes occur is not recommended due to the association of such reactions with the NNRTI class as a whole. ${ }^{24,66}$

Efavirenz-induced gynecomastia is an increasingly recognized side effect of ART in both prepubertal and pubertal children. Its etiology and natural history are still under debate. Outcomes vary from resolution after drug withdrawal to persistent gynecomastia requiring breast reduction surgery. ${ }^{30,67-69}$ Gynecomastia is most likely to be reversible if efavirenz is withdrawn before fibrotic tissue develops. ${ }^{31,70,71}$

\section{Efavirenz use in pregnancy}

The use of efavirenz in females of reproductive age is cautioned due to concern for teratogenicity. A high number of craniofacial defects in cynomolgus monkeys were seen in an unpublished but widely cited study. ${ }^{32,72}$ Case reports of human central nervous system/neural tube defects after in utero efavirenz exposure were then published, leading the FDA to reclassify efavirenz as a class D drug ("evidence of human fetal risk") in 2005. A black box warning recommends against use of efavirenz during the first trimester of pregnancy. Despite these concerns and cases, prospective reports from the Antiretroviral Pregnancy Registry and cohort studies have found no evidence of increased incidence of congenital abnormalities among infants born to pregnant women who received efavirenz compared with rates in the general population. ${ }^{33,73}$ Ford et al conducted a meta-analysis of efavirenz safety in pregnancy and found no increased risk of overall birth defects among women exposed to efavirenz during the first trimester of pregnancy compared with those exposed to other ARVs. ${ }^{74}$

The teratogenicity concerns have led to a decline in use of efavirenz in pregnancy and breastfeeding in developed countries, facilitated by the existence of numerous other treatment options. In low-resource settings, ART options are far more limited and NNRTIs represent the core firstline drugs. Ouattara et al developed a simulation model to project the outcomes of using either efavirenz or nevirapine as part of the initial ART in 100,000 women of childbearing age in Cote d'Ivoire. Using liberal assumptions regarding the teratogenicity of efavirenz, they predicted that using efavirenz would result in 911 additional maternal lives saved with a cost of 59 additional birth defects. ${ }^{75}$ Some countries specifically recommend efavirenz for first-line treatment for all adults, including women with childbearing potential. ${ }^{36,37,76,77}$ With the increased use of HAART in resource-limited settings as part of the prevention of mother-to-child HIV transmission (PMTCT) of HIV, the development of prospective surveillance systems to allow systematic recording of birth outcomes for women receiving ART during pregnancy is essential.

\section{Development of efavirenz resistance in children}

Although there is no substantial evidence that development of resistance differs in children compared with adults, children are often maintained longer on failing regimens than adults because of fewer pediatric treatment options and increased challenges with adherence. ${ }^{78} \mathrm{~A}$ systematic review of resistance data in children in low-resource countries found that $90 \%$ of those failing first-line regimens had at least one detectable mutation, increasing in frequency with longer duration of treatment failure. NNRTI-associated mutations were the most common, and found in $88 \%$ of the children. ${ }^{79}$ NNRTIs select for mutations in regions near or in the drug-binding pocket, particularly codons 98-108 and 179-190. Efavirenz has a low 
genetic barrier to resistance because a single point mutation in the reverse transcriptase gene allows for high-level resistance, increasing the $50 \%$ inhibitory concentration by up to 100 -fold. The signature mutation that appears during initial failure on efavirenz is the $\mathrm{K} 103 \mathrm{~N}$ mutation, but the $\mathrm{Y} 188 \mathrm{~L}$ mutation is also commonly seen. After prolonged periods of viral replication, other mutations often accumulate (V106M, V108I, Y181C/I, G190A/S, P225H). ${ }^{18,20,29}$

Cross-resistance between the first-generation NNRTIs usually precludes sequential use of efavirenz and nevirapine after development of resistance. Particular concerns have been raised regarding HIV-infected children in resourcelimited settings, where high rates of resistance following exposure to nevirapine for PMTCT and widespread use of first-line NNRTI-based therapy have been shown to impact the effectiveness of therapy and further reduce the treatment options. ${ }^{80-82}$ The IMPAACT P1060 and Nevirapine Resistance Study (NEVERST) clinical trials investigated whether previous exposure to nevirapine compromised subsequent nevirapine-containing regimens. IMPAACT P1060 was prematurely discontinued when the 24-week interim analysis showed that infants who had previously received single-dose nevirapine had lower rates of virological failure and death if treated with lopinavir/ritonavir-based regimens compared with nevirapine. For this reason, where feasible, a boosted protease inhibitor-based first-line regimen is recommended for children at high risk of NNRTI resistance (ie, those exposed to nevirapine as part of PMTCT). Of note, in IMPAACT P1060, lopinavir/ritonavir-containing regimens also had better outcomes compared with nevirapine in infants not exposed to nevirapine. Mutations from PMTCT may fade with time, and the degree to which they affect response to treatment in older children is less clear. ${ }^{42}$ The NEVEREST study showed that despite previous nevirapine exposure, switching to a nevirapine-based regimen after initial virologic suppression with lopinavir/ritonavir-based ART works well in some children. This trial enrolled 323 children under 2 years before efavirenz was approved for use in that age group. ${ }^{83}$

Rates of drug resistance vary between ARVs and ARV classes. The PENPACT-1 study included a second factorial randomization in order to compare the effects of switching treatment following virologic failure at $\geq 1,000$ HIV RNA copies per $\mathrm{mL}$ or $\geq 30,000$ HIV RNA copies per $\mathrm{mL}$. There was no significant difference between viral load subgroups in the development of major protease inhibitor or NNRTI resistance mutations at the end of follow-up (4 years), but significantly more children treated with NNRTIs and randomized to switch at $\geq 30,000$ HIV RNA copies per mL developed NRTI mutations compared with those treated with protease inhibitors. ${ }^{41}$

The commonly selected NNRTI mutations do not appreciably decrease the HIV replicative capacity. Therefore, there is limited benefit in continuing NNRTI therapy once resistance has emerged. Cross-resistance exists between nevirapine and efavirenz due to the narrow binding site in the hydrophobic pocket of the HIV-1 reverse transcriptase. However, cross-resistance between NNRTIs and other classes does not occur. The more recently approved NNRTIs, etravirine and rilpivirine, can still be used by many patients with resistance to the older NNRTIs. ${ }^{20,84}$ While substantially compromising both nevirapine and efavirenz, the K103N mutation does not significantly change the response to etravirine. In some patients with highly resistant virus, cross-resistance to the newer NNRTIs may exist. The Y181C mutation, frequently found in patients failing nevirapine or efavirenz, impacts the virological response to etravirine.$^{85}$ Contreras et al recently reported a series of 33 highly treatment-experienced, perinatally HIV-infected children, one third of whom had resistance to etravirine despite never having been exposed to that drug. ${ }^{86}$ Similarly, Puthanakit et al reported that $48 \%$ of 120 NNRTI-pretreated children had significant etravirine resistance. ${ }^{87}$

\section{Research recommendations}

With the increased use of ART in resource-limited settings both for treatment and for PMTCT, the development of prospective surveillance systems to allow systematic recording of birth outcomes for women receiving ART during pregnancy and to assess the incidence of rare birth defects is essential. The concerns regarding efavirenz toxicity that were brought about by nonhuman primate studies which have not yet been borne out in human experience will be thoroughly tested by large numbers of pregnant women taking efavirenz. Close monitoring of these mothers and infants is essential to quantifying any true fetal risk of efavirenz use.

Further research is also needed to determine the role of efavirenz in children exposed perinatally to nevirapine and efavirenz. In resource-limited settings where resistance tests are not routinely available prior to initiation of HAART, lopinavir/ritonavir is becoming the preferred treatment for HIV-infected infants. Whether or not these patients can be safely switched to efavirenz-based treatment after infancy and whether archived mutations will present long-term treatment challenges remain open questions. 
The higher doses of efavirenz recommended by WHO to minimize the risk for subtherapeutic efavirenz concentrations could increase toxicity levels, particularly in areas where many patients have slower-metabolizing phenotypes. Long-term side effects such as possible developmental delays and gynecomastia need to be better quantified among children with extensive experience of treatment with efavirenz, particularly at higher doses. For children impacted by efavirenz resistance and side effects, the safety and utility of newergeneration NNRTIs also needs to be assessed.

\section{Disclosure}

None of the authors have received funding relevant to this paper in the last 3 years. The authors report no other conflicts of interest in this work.

\section{References}

1. World Health Organization. UNAIDS Report on the Global Aids Epidemic. Geneva, Switzerland: World Health Organization; 2012. Available from: http://www.unaids.org/en/media/unaids/contentassets/ documents/epidemiology/2012/gr2012/20121120_unaids_global_ report_2012_with_annexes_en.pdf. Accessed March 15, 2014.

2. Violari A, Cotton MF, Gibb DM, et al. Early antiretroviral therapy and mortality among HIV-infected infants. $N$ Engl J Med. 2008;359(21):2233-2244.

3. Mofenson LM, Cotton MF. The challenges of success: adolescents with perinatal HIV infection. $J$ Int AIDS Soc. 2013;16:18650.

4. Neely M, Kovacs A. Management of antiretroviral therapy in neonates, children, and adolescents. Curr HIV/AIDS Rep. 2004;1(2): 97-104.

5. Tubiana R, Le Chenadec J, Rouzioux C, et al. Factors associated with mother-to-child transmission of HIV-1 despite a maternal viral load. Clin Infect Dis. 2010;50(4):585-596.

6. HIV Paediatric Prognostic Markers Collaborative Study. Predictive value of absolute CD4 cell count for disease progression in untreated HIV-1-infected children. AIDS. 2006;20(9):1289-1294.

7. Palumbo PE, Raskino C, Fiscus S, et al. Predictive value of quantitative plasma HIV RNA and CD4+ lymphocyte count in HIV-infected infants and children. JAMA. 1998;279(10):756-761.

8. Brady MT, Oleske JM, Williams PL, et al. Declines in mortality rates and changes in causes of death in HIV-1-infected children during the HAART era. J Acquir Immune Defic Syndr. 2010;53(1):86-94.

9. Kapogiannis BG, Soe MM, Nesheim SR, et al. Mortality trends in the US Perinatal AIDS Collaborative Transmission Study (1986-2004). Clin Infect Dis. 2011;53(10):1024-1034.

10. AIDSinfo. Guidelines for the use of antiretroviral agents in Pediatric HIV infection. 2013. Available from: http://aidsinfo.nih.gov/contentfiles/lvguidelines/pediatricguidelines.pdf. Accessed March 15, 2014.

11. Riordan A, Bugembe T. Update on antiretroviral therapy. Arch Dis Child. 2009;94(1):70-74.

12. Kim RJ, Rutstein RM. Impact of antiretroviral therapy on growth, body composition and metabolism in pediatric HIV patients. Paediatr Drugs. 2010;12(3):187-199.

13. Agwu AL, Fairlie L. Antiretroviral treatment, management challenges and outcomes in perinatally HIV-infected adolescents. J Int AIDS Soc. 2013; 16:18579.

14. de Mulder M, Yebra G, Martín L, et al. Drug resistance prevalence and HIV-1 variant characterization in the naive and pretreated HIV-1-infected paediatric population in Madrid, Spain. JAntimicrob Chemother. 2011;66(10):2362-2371.
15. Fletcher CV, Brundage RC, Fenton T, et al. Pharmacokinetics and pharmacodynamics of efavirenz and nelfinavir in HIV-infected children participating in an area-under-the-curve controlled trial. Clin Pharmacol Ther. 2007;83(2):300-306.

16. Musoke PM, Mudiope P, Barlow-Mosha LN, et al. Growth, immune and viral responses in HIV infected African children receiving highly active antiretroviral therapy: a prospective cohort study. BMC Pediatrics. 2010;10:56.

17. Ciaranello AL, Chang Y, Margulis AV, et al. Effectiveness of pediatric antiretroviral therapy in resource-limited settings: a systematic review and meta-analysis. Clin Infect Dis. 2009;49(12):1915-1927.

18. Fortin C, Joly V. Efavirenz for HIV-1 infection in adults: an overview. Expert Rev Anti Infect Ther. 2004;2(5):671-684.

19. Ntemgwa ML, d'Aquin Toni T, Brenner BG, Camacho RJ, Wainberg MA. Antiretroviral drug resistance in human immunodeficiency virus type 2. J Antimicrob Chemother. 2009;53(9):3611-3619.

20. Penazzato $M$, Giaquinto $C$. Role of non-nucleoside reverse transcriptase inhibitors in treating HIV-infected children. Drugs. 2011;71(16): 2131-2149.

21. PENTA Steering Committee. PENTA 2009 guidelines for the use of antiretroviral therapy in paediatric HIV-1 infection. HIV Med. 2009;10(10):591-613.

22. World Health Organization. Consolidated guidelines on the use of antiretroviral drugs for treating and preventing HIV infection. Geneva, Switzerland: World Health Organization. 2013. Available from: http:// apps.who.int/iris/bitstream/10665/85321/1/9789241505727_eng. pdf?ua=1. Accessed March 15, 2014.

23. Arribas JR. Efavirenz: enhancing the gold standard. Int J STD AIDS. 2003;14 Suppl 1:6-14.

24. Vrouenraets SM, Wit FW, Tongeren JV, Lange JM. Efavirenz: a review. Expert Opin Pharmacother. 2007;8(6):851-871.

25. Deeks ED, Perry CM. Efavirenz/emtricitabine/tenofovir disoproxil fumarate single-tablet regimen (Atripla ${ }^{\circledR}$ ): a review of its use in the management of HIV infection. Drugs. 2010;70(17):2315-2338.

26. Gazzard B, Duvivier C, Zagler C, et al. Phase 2 double-blind, randomized trial of etravirine versus efavirenz in treatment-naive patients. AIDS. 2011;25(18):2249-2258.

27. Osterholzer D. The role of etravirine in the management of treatment-experienced pediatric patients with HIV. HIV AIDS (Auckl). 2013;5:67-73.

28. Viani R, Dehority W. Profile of etravirine in the treatment of HIV in pediatrics. Pediatric Health, Medicine and Therapeutics. 2013;4:65-73.

29. Best BM, Goicoechea M. Efavirenz - still first-line king? Expert Opin Drug Metab Toxicol. 2008;4(7):965-972.

30. Starr SE, Fletcher CV, Spector SA, et al. Combination therapy with efavirenz, nelfinavir, and nucleoside reverse-transcriptase inhibitors in children infected with human immunodeficiency virus type 1. Pediatric AIDS Clinical Trials Group 382 Team. N Engl J Med. 1999;341(25): 1874-1881.

31. World Health Organization. Technical update on treatment optimization: Use of efavirenz during pregnancy: A public health perspective. Geneva, Switzerland: World Health Organization; 2012. Available from: http://whqlibdoc.who.int/publications/2012/9789241503792_eng.pdf. Accessed March 15, 2014.

32. Lowenthal ED, Ellenberg JH, Machine E, et al. Association between efavirenz-based compared with nevirapine-based antiretroviral regimens and virological failure in HIV-infected children. JAMA. 2013;309(17): 1803-1809.

33. Kamya MR, Mayanja-Kizza H, Kambugu A, et al. Predictors of long-term viral failure among ugandan children and adults treated with antiretroviral therapy. J Acquir Immune Defic Syndr. 2007;46(2): 187-193.

34. Salem AH, Fletcher CV, Brundage RC. Pharmacometric characterization of efavirenz developmental pharmacokinetics and pharmacogenetics in HIV-infected children. Antimicrob Agents Chemother. 2014;58(1): 136-143. 
35. Giaquinto C, Anabwani G, Feiterna-Sperling C, et al. Steady-state pharmacokinetics of nevirapine extended-release tablets in HIV-1 infected children and adolescents: an open-label, multiple dose, cross-over study. Pediatr Infect Dis J. December 30, 2013. [Epub ahead of print.]

36. Mbuagbaw LC, Irlam JH, Spaulding A, Rutherford GW, Siegfried N. Efavirenz or nevirapine in three-drug combination therapy with two nucleoside-reverse transcriptase inhibitors for initial treatment of HIV infection in antiretroviral-naïve individuals. Cochrane Database Syst Rev. 2010;12:CD004246.

37. van Leth F, Phanuphak P, Ruxrungtham K, et al. Comparison of first-line antiretroviral therapy with regimens including nevirapine, efavirenz, or both drugs, plus stavudine and lamivudine: a randomised open-label trial, the 2NN Study. Lancet. 2004;363(9417):1253-1263.

38. Evans D, Menezes C, Mahomed K, et al. Treatment outcomes of HIV-infected adolescents attending public-sector HIV clinics across Gauteng and Mpumalanga, South Africa. AIDS Res Hum Retroviruses. 2013;29(6):892-900.

39. Médecins Sans Frontières. Untangling the web of antiretroviral price reductions. 14th ed. Geneva, Switzerland: Médecins Sans Frontières 2011. Available from: http://apps.who.int/medicinedocs/documents/ s18716en/s18716en.pdf. Accessed March 15, 2014.

40. Squires K, Lazzarin A, Gatell JM, et al. Comparison of once-daily atazanavir with efavirenz, each in combination with fixed-dose zidovudine and lamivudine, as initial therapy for patients infected with HIV. J Acquir Immune Defic Syndr. 2004;36(5):1011-1019.

41. PENPACT-1 (PENTA 9/PACTG 390) Study Team; Babiker A, Castro nee Green $\mathrm{H}$, et al. First-line antiretroviral therapy with a protease inhibitor versus non-nucleoside reverse transcriptase inhibitor and switch at higher versus low viral load in HIV-infected children: an open-label, randomised phase 2/3 trial. Lancet Infect Dis. 2011;11(4):273-283.

42. Palumbo P, Lindsey JC, Hughes MD, et al. Antiretroviral treatment for children with peripartum nevirapine exposure. $N \mathrm{Engl} \mathrm{J} \mathrm{Med}$. 2010;363(16):1510-1520.

43. Violari A, Lindsey JC, Hughes MD, et al. Nevirapine versus ritonavirboosted lopinavir for HIV-infected children. $N$ Engl J Med. 2012; 366(25):2380-2389.

44. McComsey G, Bhumbra N, Ma JF, Rathore M, Alvarez A. Impact of protease inhibitor substitution with efavirenz in HIV-infected children: results of the first pediatric switch study. Pediatrics. 2003;111(3): e275-e281.

45. Kaul S, Ji P, Lu M, Nguyen KL, Shangguan T, Grasela D. Bioavailability in healthy adults of efavirenz capsule contents mixed with a small amount of food. Am J Health Syst Pharm. 2010;67(3):217-222.

46. Wintergerst U, Hoffmann F, Jansson A, et al. Antiviral efficacy, tolerability and pharmacokinetics of efavirenz in an unselected cohort of HIVinfected children. J Antimicrob Chemother. 2008;61(6):1336-1339.

47. Hirt D, Urien S, Olivier M, et al. Is the recommended dose of efavirenz optimal in young West African human immunodeficiency virus-infected children? J Antimicrob Chemother. 2009;53(10):4407-4413.

48. Fillekes Q, Natukunda E, Balungi J, et al. Pediatric underdosing of efavirenz: a pharmacokinetic study in Uganda. J Acquir Immune Defic Syndr. 2011;58(4):392-398.

49. Mutwa PR, Fillekes Q, Malgaz M, et al. Mid-dosing interval efavirenz plasma concentrations in HIV-1-infected children in Rwanda: treatment efficacy, tolerability, adherence, and the influence of CYP2B6 polymorphisms. J Acquir Immune Defic Syndr. 2012;60(4):400-404.

50. Starr SE, Fletcher CV, Spector SA, et al. Efavirenz liquid formulation in human immunodeficiency virus-infected children. Pediatr Infect Dis J. 2002;21(7):659-663.

51. Naftalin CM, Chan K, Wong KH, Cheung SW, Chan R, Lee SS. CYP2B6-G516T genotype influences plasma efavirenz concentration in a Hong Kong population, allowing potential individualization of therapy. HIV Med. 2013;15(1):63-64.

52. Saitoh A, Fletcher CV, Brundage R, et al. Efavirenz pharmacokinetics in HIV-1-infected children are associated with CYP2B6-G516T polymorphism. J Acquir Immune Defic Syndr. 2007;45(3):280-285.
53. Ståhle L, Moberg L, Svensson J-O, Sönnerborg A. Efavirenz plasma concentrations in HIV-infected patients: inter- and intraindividual variability and clinical effects. Ther Drug Monit. 2004;26(3):267-270.

54. Kappelhoff BS, van Leth F, Robinson PA, et al. Are adverse events of nevirapine and efavirenz related to plasma concentrations? Antivir Ther. 2005;10(4):489-498.

55. McIlleron HM, Schomaker M, Ren Y, et al. Effects of rifampin-based antituberculosis therapy on plasma efavirenz concentrations in children vary by CYP2B6 genotype. AIDS. 2013;27(12):1933-1940.

56. Bonnet M, Bhatt N, Baudin E, et al. ArticlesNevirapine versus efavirenz for patients co-infected with HIV and tuberculosis: a randomised noninferiority trial. Lancet Infect Dis. 2013;13(4):303-312.

57. Pérez-Molina JA. Safety and tolerance of efavirenz in different antiretroviral regimens: results from a national multicenter prospective study in 1,033 HIV-infected patients. HIV Clin Trials. 2002;3(4): 279-286.

58. Treisman GJ, Kaplin AI. Neurologic and psychiatric complications of antiretroviral agents. AIDS. 2002;16(9):1201-1215.

59. Kenedi CA, Goforth HW. A systematic review of the psychiatric sideeffects of efavirenz. AIDS Behav. 2011;15(8):1803-1818.

60. Marzolini C, Telenti A, Decosterd LA, Greub G, Biollaz J, Buclin T. Efavirenz plasma levels can predict treatment failure and central nervous system side effects in HIV-1-infected patients. AIDS. 2001;15(1): 71-75.

61. Fumaz CR, Muñoz-Moreno JA, Moltó J, et al. Long-term neuropsychiatric disorders on efavirenz-based approaches: quality of life, psychologic issues, and adherence. J Acquir Immune Defic Syndr. 2005; 38(5):560-565.

62. Lee GM. Quality of life for children and adolescents: impact of HIV infection and antiretroviral treatment. Pediatrics. 2006;117(2):273-283.

63. Tukei VJ, Asiimwe A, Maganda A, et al. Safety and tolerability of antiretroviral therapy among HIV-infected children and adolescents in Uganda. J Acquir Immune Defic Syndr. 2012;59(3):274-280.

64. Kontorinis N, Dieterich DT. Toxicity of non-nucleoside analogue reverse transcriptase inhibitors. Semin Liver Dis. 2003;23(2):173-182.

65. Shubber Z, Calmy A, Andrieux-Meyer I, et al. Adverse events associated with nevirapine and efavirenz-based first-line antiretroviral therapy. AIDS. 2013;27(9):1403-1412.

66. Mehta U, Maartens $G$. Is it safe to switch between efavirenz and nevirapine in the event of toxicity? Lancet Infect Dis. 2007;7(11):733-738.

67. van Ramshorst MS, Kekana M, Struthers HE, McIntyre JA, Peters RP. Efavirenz-induced gynecomastia in a prepubertal girl with human immunodeficiency virus infection: a case report. BMC Pediatrics. 2013;13(1):1-1.

68. Jover F, Cuadrado JM, Roig P, Rodríguez M, Andreu L, Merino J. Efavirenz-associated gynecomastia: report of five cases and review of the literature. Breast J. 2004;10(3):244-246.

69. Meerkotter D. Gynaecomastia associated with highly active antiretroviral therapy (HAART). J Radiol Case Rep. 2010;4(7):34-40.

70. Bernasconi E, Boubaker K, Junghans C, et al. Abnormalities of body fat distribution in HIV-infected persons treated with antiretroviral drugs: the Swiss HIV Cohort Study. J Acquir Immune Defic Syndr. 2002;31(1): 50-55.

71. Caso JA, Prieto J de M, Casas E, Sanz J. Gynecomastia without lipodystrophy syndrome in HIV-infected men treated with efavirenz. AIDS. 2001;15(11):1447-1448.

72. Nightingale SL. From the Food and Drug Administration. JAMA. 1998;280(17):1472.

73. Ford N, Calmy A. Efavirenz is not a known teratogen. Pediatr Infect Dis J. 2012;31(9):999.

74. Ford N, Mofenson L, Kranzer K, et al. Safety of efavirenz in firsttrimester of pregnancy: a systematic review and meta-analysis of outcomes from observational cohorts. AIDS. 2010;24(10):1461-1470.

75. Ouattara EN, Anglaret X, Wong AY, et al. Projecting the clinical benefits and risks of using efavirenz-containing antiretroviral therapy regimens in women of childbearing age. AIDS. 2012;26(5):625-634. 
76. The South African Antiretroviral Treatment Guidelines 2013. Available from: http://www.sahivsoc.org/upload/documents/Clinical_Guidelines_ for_the_Management_of_HIV_AIDS_in_Adults_Adolescents_2010. pdf. 2013:1-14. Accessed March 15, 2014.

77. Botswana National HIV and AIDS Treatment Guidelines. Available from: wwwaidstar-onecom/sites/default/files/Botswana_2012_taggedpdf. Accessed March 15, 2014.

78. Fitzgerald F, Penazzato M, Gibb D. Development of antiretroviral resistance in children with HIV in low- and middle-income countries. J Infect Dis. 2013;207 Supp1 2:S85-S92.

79. Sigaloff KC, Calis JC, Geelen SP, van Vugt M, de Wit TF. HIV-1resistance-associated mutations after failure of first-line antiretroviral treatment among children in resource-poor regions: a systematic review. Lancet Infect Dis. 2011;11(10):769-779.

80. Lockman S, Shapiro RL, Smeaton LM, et al. Response to antiretroviral therapy after a single, peripartum dose of nevirapine. $N$ Engl J Med. 2007;356(2):135-147.

81. MacLeod IJ, Rowley CF, Thior I, et al. Minor resistant variants in nevirapine-exposed infants may predict virologic failure on nevirapinecontaining ART. J Clin Virol. 2010;48(3):162-167.

82. Musiime V, Ssali F, Kayiwa J, et al. Response to nonnucleoside reverse transcriptase inhibitor-based therapy in HIV-infected children with perinatal exposure to single-dose nevirapine. AIDS Res Hum Retroviruses. 2009;25(10):989-996.

83. Moorthy A, Kuhn L, Coovadia A, et al. Induction therapy with proteaseinhibitors modifies the effect of nevirapine resistance on virologic response to nevirapine-based HAART in children. Clin Infect Dis. 2011;52(4):514-521.

84. Ford N, Lee J, Andrieux-Meyer I, Calmy A. Safety, efficacy, and pharmacokinetics of rilpivirine: systematic review with an emphasis on resource-limited settings. HIV AIDS (Auckl). 2011;3:35-44.

85. Vingerhoets J, Tambuyzer L, Azijn H, et al. Resistance profile of etravirine: combined analysis of baseline genotypic and phenotypic data from the randomized, controlled Phase III clinical studies. AIDS. 2010;24(4):503-514.

86. Contreras GA, Bell CS, Del Bianco GP, et al. Prevalence and risk factors associated with resistance-associated mutations to etravirine in a cohort of perinatally HIV-infected children. J Antimicrob Chemother. 2013;68(10):2344-2348.

87. Puthanakit T, Jourdain G, Hongsiriwon S, et al. HIV-1 drug resistance mutations in children after failure of first-line nonnucleoside reverse transcriptase inhibitor-based antiretroviral therapy. HIV Med. 2010;11(9):565-572.
88. Teglas JP, Quartier P, Treluyer JM, Burgard M, Gregoire V, Blanche S. Tolerance of efavirenz in children. AIDS. 2001;15(2):241-243.

89. Engelhorn C, Hoffmann F, Notheis G, et al. Effect of antiretroviral combination therapies including efavirenz in heavily pretreated HIVinfected children. Eur J Med Res. 2002;7(1):30-34

90. Fraaij PL, Neubert J, Bergshoeff AS, et al. Safety and efficacy of a NRTI-sparing HAART regimen of efavirenz and lopinavir/ritonavir in HIV-1-infected children. Antivir Ther. 2004;9(2):297-299.

91. Funk MB, Notheis G, Schuster T, et al. Effect of first line therapy including efavirenz and two nucleoside reverse transcriptase inhibitors in HIV-infected children. Eur J Med Res. 2005;10(12):503-508.

92. McKinney RE, Rodman J, Hu C, et al. Long-term safety and efficacy of a once-daily regimen of emtricitabine, didanosine, and efavirenz in HIV-infected, therapy-naive children and adolescents: Pediatric AIDS Clinical Trials Group Protocol P1021. Pediatrics. 2007;120(2): e416-e423.

93. Scherpbier HJ, Bekker V, Pajkrt D, Jurriaans S, Lange JM, Kuijpers TW. Once-daily highly active antiretroviral therapy for HIV-infected children: safety and efficacy of an efavirenz-containing regimen. Pediatrics. 2007;119(3):e705-e715.

94. Barro M, Some J, Foulongne V, et al. Short-term virological efficacy, immune reconstitution, tolerance, and adherence of once-daily dosing of didanosine, lamivudine, and efavirenz in HIV-1-infected African children: ANRS 12103 Burkiname. J Acquir Immune Defic Syndr. 2011;57 Suppl 1:S44-S49.

95. Hien H, Meda N, Diagbouga S, et al. 24-Month adherence, tolerance and efficacy of once-a-day antiretroviral therapy with didanosine, lamivudine, and efavirenz in African HIV-1 infected children: ANRS 12103/12167. Afr Health Sci. 2013;13(2):287-294.

96. Ren Y, Nuttall JJC, Egbers C, et al. High prevalence of subtherapeutic plasma concentrations of efavirenz in children. J Acquir Immune Defic Syndr. 2007;45(2):133-136.

97. Viljoen M, Gous H, Kruger HS, Riddick A, Meyers TM, Rheeders M. Efavirenz plasma concentrations at 1,3, and 6 months post-antiretroviral therapy initiation in HIV type 1-infected South African children. AIDS Res Hum Retroviruses. 2010;26(6):613-619.

98. Cressey TR, Aurpibul L, Narkbunnam T, et al. Pharmacological assessment of efavirenz weight-band dosing recommendations in HIV-infected Thai children. J Acquir Immune Defic Syndr. 2013;62(1):e27-e29.
Pediatric Health, Medicine and Therapeutics

\section{Publish your work in this journal}

Pediatric Health, Medicine and Therapeutics is an international, peerreviewed, open access journal publishing original research, reports, editorials, reviews and commentaries. All aspects of health maintenance, preventative measures and disease treatment interventions are addressed within the journal. Practitioners from all disciplines are invited to submit

\section{Dovepress}

their work as well as healthcare researchers and patient support groups. The manuscript management system is completely online and includes a very quick and fair peer-review system. Visit http://www.dovepress.com/ testimonials.php to read real quotes from published authors. 